\title{
An investigation into the output tax consequences of bitcoin transactions for a South African value-added tax vendor
}

Author:
Cecileen Greeff ${ }^{1}$
Affiliation:
'Department of Economic
and Management Sciences,
School of Accountancy,
Stellenbosch University,
Stellenbosch, South Africa
Corresponding author:
Cecileen Greeff,
cgreeff@sun.ac.za
Dates:
Received: 25 Oct. 2017
Accepted: 24 Jan. 2019
Published: 25 Apr. 2019
How to cite this article:
Gead online:
Greeff, C., 2019, 'An
investigation into the output
tax conseguences of bitcoin
transactions for a South
African value-added tax
to read online.
vendor', South African Journal
of Economic and Management
Sciences $22(1)$, a2162. https://
doi.org/10.4102/sajems.
v22i1.2162
Copyright:
(c) 2019. The Authors.
Licensee: AOSIS. This work
is licensed under the
Creative Commons
Attribution License.

Background: The use of bitcoin in South Africa is fairly new, but has increased as several online retailers now accept bitcoin as a means of payment. The South African Revenue Service has released a media statement regarding the normal tax treatment of cryptocurrencies (such as bitcoin), but policy regarding the value-added tax (VAT) treatment of cryptocurrencies is still pending.

Aim: The objective of the study is to determine the output tax consequences for a South African VAT vendor who receives bitcoins in exchange for the supply of goods or services that are subject to VAT, and when the same South African VAT vendor exchanges the bitcoins for South African rand at a local exchange platform.

Setting: This article examines existing literature in a South African VAT environment.

Method: A non-empirical study based on existing literature is performed.

Results: It is found that when interpreting the (current) VAT Act No. 89 of 1991, the receiving of bitcoin in exchange for the supply of goods or services, as well as the exchange of bitcoin for South African rand, is subject to output tax at the standard rate of $14 \%$, which will lead to 'double taxation'.

Conclusion: It was shown through this study that the proposed treatment as explained in the previous section would impose 'double taxation'.

Keywords: Bitcoin; Output tax; VAT; VAT Act No. 89 of 1991; South Africa.

\section{Introduction and background}

Bitcoin is a virtual cryptocurrency that exists in electronic form (Berger 2016). It was launched in 2009 by Satoshi Nakamoto (Franco 2015:108; Chuen \& Deng 2018:177). Bitcoin is defined as a 'digital representation of value that is neither issued by a central bank or a public authority, not necessarily attached to a Fiat currency, but is accepted by natural or legal persons as a means of payment and can be transferred, stored or traded electronically' (European Banking Authority [EBA] 2014:5). Bitcoin can be held as an investment or can be exchanged for goods and services, such as buying physical goods and services using online stores (Berger 2016:1). Bitcoin as a means of payment for goods and services has grown substantially over the past few years, and merchants are more prone to accept bitcoin due to fees being lower than the typical credit card processors. More than 100 South African merchandisers are accepting bitcoin as a method of payment (Visser 2016).

The two most established bitcoin exchange platforms, where one can buy and sell bitcoin in South Africa, are Luno and $\mathrm{ICE}^{3} \mathrm{X}$, of which Luno is the biggest in terms of user base and trading volumes (Bitcoin ZAR n.d.). Luno, founded in February 2014, is South Africa's first rand-tobitcoin exchange platform with its headquarters in Singapore and a development team in Cape Town (Berger 2016:2). The number of bitcoins traded on $\mathrm{ICE}^{3} \mathrm{X}$ is negligible (Van Rooyen 2018). The number of bitcoins traded in South Africa on Luno has increased from 1000 bitcoins per week in 2016 to between 4000 and 7000 bitcoins per week as of 09 November 2017 (BusinessTech n.d.). Figure 1 (C. De Kock [Data request response] pers. comm., 21 May 2018; Luno Exchange 2018) shows the number of bitcoins that were exchanged for South African rand on the Luno exchange platform for the period 01 March 2017 to 28 February 2018 (total of 217017 bitcoins). What is of further interest is bitcoin's value since its inception in 2009. From 2009 to early 2013, 1 bitcoin was worth between 10 and 20 dollars. Since early 2013, however, its value has skyrocketed, to over 


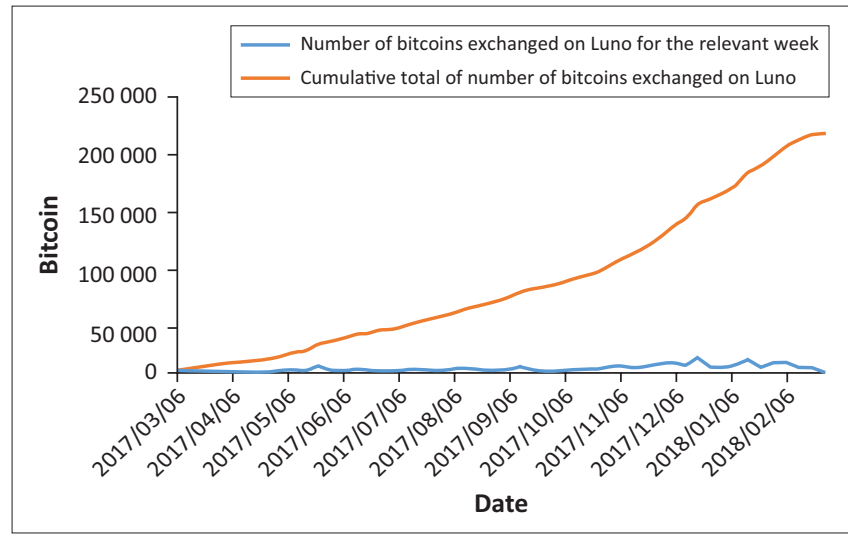

Note: Please see the full reference list of the article, Greeff, C., 2019, 'An investigation into the output tax consequences of bitcoin transactions for a South African value-added tax vendor', South African Journal of Economic and Management Sciences 22(1), a2162. https://doi.org/10.4102/sajems.v22i1.2162, for more information.

FIGURE 1: The number of bitcoins exchanged for South African rand on Luno for the period 01 March 2017 to 28 February 2018.

\$1000 per bitcoin around December 2013 (Seforo 2014) and $\$ 9900$ (approximately R130 000) in November 2017 (Bitcoin ZAR n.d.). The value of bitcoin is based upon the demand for or the willingness of members of the virtual community to accept the currency in exchange for other items of distinct value (Wicht 2016:20).

The user alert issued by National Treasury on 18 September 2014 explains that virtual currencies such as bitcoin cannot be classified as legal tender as any merchant may refuse them as a payment instrument without being in breach of the law (National Treasury 2014). The South African Revenue Service (SARS) issued a media statement on 06 April 2018 regarding the normal tax treatment of cryptocurrencies such as bitcoin, but there is no published ruling, tax court decision or publication by government of interpretation notes on the VAT considerations of bitcoin (SARS 2018b; Wicht 2016:10). However, during October 2018 National Treasury (2018:51) proposed to include the issue, acquisition, collection, buying or selling or transfer of ownership of any cryptocurrency' as a financial service, which is an exempt supply for VAT, in the Taxation Laws Amendment Bill of 2018. The VAT consequences of bitcoin transactions therefore require investigation in an attempt to provide guidance on the consequences in terms of the (current) Value-Added Tax Act No. 89 of 1991 (hereinafter 'the Act') in South Africa.

For a transaction to attract VAT consequences, the requirements of 'supply' of 'goods' or 'services' in 'the furtherance of any enterprise' must be met. 'Supply' contains a wide definition in terms of section 1 of the Act, which could include any provision of goods or services in the course of the business of a taxpayer (De Koker \& Kruger 2017). Section 1 of the Act defines 'goods' as any corporeal movable thing, fixed property or any right in any such thing. According to section 1 of the Act the definition of 'services' would apply in instances where 'goods' are not supplied. The 'furtherance of an enterprise' requires that goods or services must be supplied for 'consideration' - thus payment in any form. Should these requirements be met, VAT will have to be levied at the standard, rate of $14 \%$. Given the proposed treatment in the Taxation Laws Amendment Bill of 2018 (National Treasury 2018:51), the uncertainty of interest highlighted in this article is the possible exemption of the exchange of bitcoin by a South African VAT vendor for South African rand in terms of section 12(1) of the Act, which exempt any financial service from VAT. Uncertainty therefore exists as to whether the exchange of goods or services for bitcoin is subject to VAT at the standard rate of $14 \%$, and whether the exchange of bitcoin for South African rand could qualify as the exchange of currency which is specifically included as a financial service in section 2(1) of the (current) Act.

\section{Research objectives, scope and value of research}

In its first interim report on Base Erosion and Profit Shifting, the Davis Tax Committee states that the use of bitcoin and other virtual currencies is increasing (Davis Tax Committee 2014). The Organisation for Economic Cooperation and Development (OECD) published an Action Plan on Base Erosion and Profit Shifting in July 2013 in response to the growing use of virtual currencies such as bitcoin (OECD 2013). Their working paper highlighted two issues: (1) the tax treatment of capital gain and losses in the cryptocurrency world, and (2) anonymity to avoid taxes with the use of virtual currencies (OECD 2013). South Africa is one of the non-member economies with which the OECD has work relationships (Wicht 2016:12). On 18 September 2014 the National Treasury, the South African Reserve Bank (SARB), the Financial Services Board, SARS and the Financial Intelligence Centre issued a joint statement to warn the South African public of the risks associated with the use of virtual currencies for investments and transactions (National Treasury 2014). It is therefore evident that there is a need to address the VAT consequences of bitcoin transactions in a South African context as virtual currencies are becoming increasingly popular among South Africans to purchase goods and services (National Treasury 2014).

The objective of this research is to investigate the output tax consequences of bitcoin transactions in South Africa from the perspective of a South African VAT vendor based on a detailed understanding of what bitcoins are, how bitcoins work, a review of current VAT (or goods and services tax [GST] as it is known in other countries) legislation of other countries, as well as an analysis of the (current) Act. Findings of this research could assist the South African regulator to evaluate the proposed treatment contained in the Taxation Laws Amendment Bill of 2018 (National Treasury 2018:51) in terms of the output tax treatment of bitcoin transactions incurred by a South African VAT vendor. Consequently, the following two research questions provide context regarding the uncertainty of output tax compliance of bitcoin transactions (as set out in Figure 2 with examples):

- Research question 1: What are the output tax consequences for a South African VAT vendor who receives bitcoin in exchange for services rendered or goods delivered 


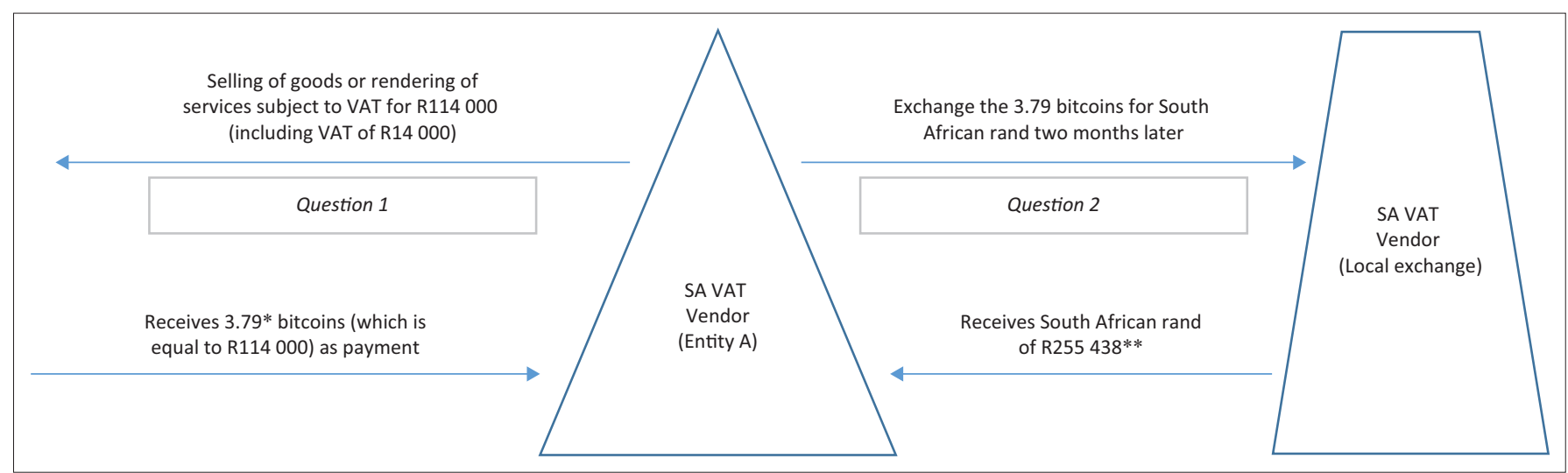

Source: Adapted from Bitcoin ZAR, n.d., South African Bitcoin resources: The official site [Online], viewed 17 May 2018, from https://www.bitcoinzar.co.za/

*, Value as on 20 June 2017; **, Value as on 15 August 2017.

VAT, value-added tax.

FIGURE 2: Two research questions (with examples).

(presumably to another South African VAT vendor) which are subject to VAT?

- Research question 2: What are the output tax consequences for the same South African VAT vendor, if the vendor exchanges the bitcoin on a local exchange (presumably to another South African VAT vendor) for South African rand (ignoring any fees or commission payable)?

A non-empirical study of existing literature was performed. A doctrinal research approach was followed, which includes the following steps (Hutchinson \& Duncan 2012):

- Gathering all the relevant facts.

- Identifying the legal issue.

- Analysing the legal issue from a legal perspective.

- Collecting and studying research sources such as statutory laws, case law, interpretations and guides from SARS, academic articles, dissertations, academic books and nonacademic articles.

- Analysing primary research sources such as legislation.

- Combining all issues within the context.

- Drawing up a conclusion.

The article is structured as follows in order to address the two research questions:

- A discussion of the functioning of bitcoin.

- A review of the output tax implication of bitcoin transactions in five other countries.

- A discussion of the requirements for a transaction in South Africa to be subject to output tax.

- Results, conclusion and recommendations for further research.

The study can potentially highlight areas for improvement or, at least, for consideration by the South African regulator to clarify the output tax treatment of bitcoin transactions for a South African VAT vendor. The study can potentially also assist taxpayers to be aware of the potential output tax consequences of relevant new transactions and to correctly apply the Act in their VAT returns in relation to bitcoin transactions. This could prevent possible unfair VAT consequences to either South African taxpayers or the fiscus.

\section{Bitcoin}

Bitcoin was invented by an anonymous user 'Sathoshi Nakamoto' in 2008 (Nakamoto 2008) and released as open source software in 2009 (Franco 2015:108). It is an 'open source' medium of exchange that is acquired, held and traded electronically without the involvement or control of an intermediary such as a bank, Western Union, Moneygram, Paypal, any company or the government (Franco 2015:5; National Treasury 2014; Thomas \& Rudman 2016:24; Wiseman 2016:420). It is therefore a virtual currency which cannot be redeemed for gold or other commodity (Berger 2016), but is traded electronically and functions as a unit of account or a store of value (Wiseman 2016:420). The European Banking Authority (EBA) defines bitcoin as 'a digital representation of value that is neither issued by a central bank or a public authority, not necessarily attached to a Fiat currency, but is accepted by natural or legal persons as a means of payment and can be transferred, stored or traded electronically' (EBA 2014:5).

There are several methods available to acquire bitcoins, which includes the following (Wiseman 2016:421):

- Receiving bitcoins as payment when selling goods or rendering services.

- Buying bitcoins at a bitcoin exchange.

- Mining for bitcoins.

Bitcoin is created digitally, by a community of people that anyone can join, through a computer process known as bitcoin mining. Bitcoin mining uses computing power (software programs that follow a mathematical formula) and specialised hardware in a distributed network (Franco 2015:46-48; Wiseman 2016:421). The bitcoin system makes use of a shared and public database or ledger (known as a block chain) to keep record of the number of bitcoins a person owns at a certain point in time (Seforo 2014). New bitcoins are created 
when a new block, comprising several transactions, is attached to the block chain once a complex algorithm is solved by a miner for a reward of 12.5 bitcoins ( 25 bitcoins until July 2016) (Franco 2015:16; Wiseman 2016:421). Solving the algorithm confirms the validity of the block's transactions by providing mathematically that the transaction occurred, and does not constitute double spending of bitcoins. Therefore, once a transaction is committed to the block chain, it is irreversible (Wiseman 2016:421). When paying for goods or services using bitcoin, the transaction is added to the block chain, and will result in a decrease in the payer's quantity of bitcoins and a corresponding increase in the quantity of the payee's bitcoins (Seforo 2014). Bitcoins are stored online in a digital wallet which is installed as an application on a computer, laptop or smartphone (Franco 2015:17-18), but one could also exchange ordinary money (such as South African rand) for bitcoin at bitcoin exchanges all over the world (Seforo 2014; Wiseman 2016:521).

Since 2009 there have been 236165171 bitcoin transactions up until 30 June 2017 and 16419900 bitcoins in circulation on 30 June 2017 (Blockchain n.d.). The bitcoin protocol stipulates that only 21 million units of bitcoin can ever be created by the miners (Ah Kun 2014; Chuen \& Deng 2018:177), which is predicted to be reached in 2140 (Wicht 2016:12). However, these bitcoins can be divided into smaller parts (the smallest divisible amount is one hundred millionth of a bitcoin and is called 'Satoshi') (Bitcoin ZAR n.d.).

\section{Comparison of the value-added tax treatment of bitcoin transactions across countries}

Due to the recent development of digital currencies (including bitcoin), there is no global consensus on the VAT treatment of bitcoin transactions (Ram 2018:217). Different tax jurisdictions treat it in different ways, depending on the objectives of the local authorities and on the way that their tax system operates (Australian Government 2016:3). Five countries (Australia, United Kingdom, Italy, Japan and Singapore) have developed and issued views, interpretations and guidelines to taxpayers regarding the tax treatment of bitcoin transactions (Australian Government 2016; EY 2016; Her Majesty's Revenue and Customs [HMRC] 2014; Moskowitz 2014; Young 2017b). The taxation systems of the five countries are very similar to the taxation system of South Africa (Berger 2016:10; Wicht 2016:15) and four of the five countries are members of the OECD (OECD n.d.). The VAT consequences relating to bitcoin transactions in the five countries are outlined below.

\section{Australia}

Recently the Australian government exempted bitcoin trading from GST in the 2017/2018 Budget Report (Young 2017b). This will ensure that consumers are no longer 'double taxed' when using bitcoin to buy goods and services already subject to GST (Suberg 2017). The Australian Treasury changed its regulations and taxation policies on bitcoin after seeing a sharp decline in interest in bitcoin in the country (Suberg 2017; Young 2017b). From 01 July 2017 bitcoin is treated as money in Australia, but GST still applies when exchanging those digital currencies for other goods and services that are themselves subject to GST (Young 2017a). When purchasing and selling bitcoin through regulated exchanges and trading platforms, the transactions are not subject to GST (Young 2017a).

Before 01 July 2017 Australia did not recognise bitcoin as 'money' for GST purposes nor as a foreign currency (Australian Government: Australian Taxation Office [ATO] 2014; PwC 2016). The ATO released several rulings on the GST of bitcoin in December 2014. For the GST treatment of bitcoin, the ATO ruling outlined that bitcoin is considered a form of intangible property under the New Tax System (Goods and Services) Act 1999 (GST Act) and the New Tax System (Goods and Services Tax) Regulations 1999 (GST Regulations) (Australian Government 2016). This resulted in the exchange of bitcoin for money to be subject to GST; where bitcoin is exchanged for other taxable goods or services the transaction is also subject to GST as it is the exchange of property for property (Australian Government 2016:2).

\section{United Kingdom}

The Revenue and Customs Brief 9 (HMRC 2014), published on 03 March 2014, sets out the position on the tax treatment of income received from and charges made in connection with activities involving bitcoin and other similar cryptocurrencies. In March 2014, HMRC outlined that when bitcoin is exchanged for foreign currencies, such as euro or dollar, no VAT is due on the value of the bitcoins themselves, as they are recognised as 'other negotiable instruments' (Australian Government 2016; HMRC 2014; Saunders 2015). When bitcoin is received in return for the provision of goods or services, the value of bitcoin in sterling at the point the transaction takes place is subject to VAT in the normal way (HMRC 2014; Saunders 2015).

\section{Italy}

The Italian Tax Authorities have issued guidance on the VAT treatment of bitcoin in Resolution no. 72 which is dated 02 September 2016 (EY 2016). Bitcoins are classified as financial transactions and it also clarifies that bitcoin transactions undertaken by businesses should be considered to be VAT exempt services (EY 2016). The Tax Authorities of Italy consider that bitcoin transactions should be included in the definition of 'transactions related to foreign currency with an official exchange rate and credits in foreign currency', regulated by Article 10, paragraph 3 of the Italian VAT Law. This Italian guidance on bitcoin transactions references the decision reached by the Court of Justice of the European Union (CJEU) in case C-264/14 Skatteverket v David Hedquist. On 22 October 2015 the CJEU ruled that in this case it was evident that the taxpayer, Mr Hedqvist, wished to deliver 
the service of an exchange of traditional currencies for bitcoin (and vice versa), which constituted a supply of services that should be exempt from VAT (EY 2016). This was based on the grounds that the bitcoins had no other purpose other than to be a means of payment. As a result, the CJEU held that Article 135(1)(e) of the European VAT Law also covered the supply of services which consisted of the exchange of traditional currencies for bitcoin (and vice versa) (EY 2016).

\section{Japan}

On 01 April 2017 Japan officially declared bitcoin's exemption from consumption tax (similar to VAT) and eliminated the possibility of double taxation on trading (Young 2017b).

\section{Singapore}

The Inland Revenue Authority of Singapore (IRAS) gave guidelines regarding the GST treatment in bitcoin exchanges in 2014 (Moskowitz 2014). The IRAS regards the exchange of bitcoin in return for consideration in money or in kind to be a taxable supply of services which is subject to GST at $7 \%$. Therefore, if the seller of the bitcoins is a GST-registered person, they would have to account for output tax on the sale of the bitcoins in the furtherance of their business (Moskowitz 2014). Where bitcoins are accepted as payment for goods or services, the transactions are treated as barter transactions. GST should be accounted for on the individual supply made, thus the supply of the goods or services and the supply of the bitcoins, if the parties are registered for GST. This would mean potential double taxation of GST, as the seller of the goods or services will be liable for GST as well as the customer. But, if the bitcoins are used in exchange for virtual goods or services (such as virtual gaming), the supply of bitcoins will not be a taxable supply (Moskowitz 2014).

According to IRAS the supply of bitcoins is not a supply of money as bitcoins do not meet the requirements of the definition of 'money' or 'currency' under the GST Act (Moskowitz 2014). Therefore, the supply of bitcoins is treated as a supply of services or goods as it involves the granting of the interest in or right over the bitcoins (Pasick 2014). It will thus attract GST.

Table 1 summarises the different output tax consequences of bitcoin transactions in Australia, the United Kingdom, Italy, Japan and Singapore in terms of the two research questions.

\begin{tabular}{lll}
\multicolumn{2}{l}{ TABLE 1: Summary of different } & output tax consequences by country \\
\hline Country & Question 1 & Question $\mathbf{2}$ \\
\hline Australia & Output VAT & Exempt supply \\
United Kingdom & Output VAT & Exempt supply \\
Italy & Output VAT & Exempt supply \\
Japan & Output VAT & Exempt supply \\
Singapore & Output VAT & Output VAT \\
\hline
\end{tabular}

VAT, value-added tax

\section{Methodology}

Based on data retrieved from Luno Exchange (2018) the average price per bitcoin for the period 01 March 2017 to 28 February 2018 was R86 157. By multiplying the average price per bitcoin by the number of bitcoins that were exchanged for South African rand (as in Figure 1) for the same period, the result is an amount of R18 697533669 . It is difficult to link these exchanges to South African VAT vendors, due to the anonymity of bitcoin trades (BusinessTech n.d.). For the purposes of this study, the assumption is made that $1 \%$ of the exchanges relates to exchanges made by South African VAT vendors; the result is an amount of R186 975337 which is possibly subject to output tax at a rate of $14 \%$.

To evaluate the above, the South African requirements for a transaction to be subject to output tax are analysed in the next section to assist formulation of the potential output tax treatment of bitcoin transactions (as set out in the two research questions) for South African VAT vendors. This is done after understanding the functioning of bitcoins as well as reviewing the output tax implication of bitcoin transactions in five other countries that have already issued guidelines for the VAT treatment of bitcoin transactions (discussed in the previous section).

\section{Analysis of South African output tax treatment}

According to the Act VAT is levied at a rate of $14 \%$ (which was increased to $15 \%$ from 01 April 2018) in South Africa (De Koker \& Kruger 2017; SARS 2018a). VAT is an indirect tax which means that the tax is indirectly assessed by SARS through the taxation of transactions (De Koker \& Kruger 2017). It is basically a tax on the consumption of goods or services in South Africa (De Koker \& Kruger 2017).

In South Africa, output tax is the tax charged by the vendor on the selling price of goods or services according to section 7(1)(a) of the Act. The selling price of the goods or services is normally VAT inclusive. The VAT levied on the selling of goods or services must be paid over to SARS. Taxable supplies can either be supplies at the standard rate of $14 \%$ or supplies charged at the zero rate $(0 \%)$. If the vendor acquired taxable supplies of goods or services from another vendor (the supplier), the VAT paid on such expenditure may be claimed as an input tax at a rate of 14\% (SARS 2017:39). Section 7(1)(a) of the Act reads verbatim as follows:

Subject to the exemptions, exceptions, deductions and adjustments provided for in this Act, there shall be levied and paid for the benefit of the National Revenue Fund a tax, to be known as the value-added tax -

(a) on the supply by any vendor of goods or services supplied by him on or after the commencement date in the course or furtherance of any enterprise carried on by him; ... calculated at the rate of 14 per cent on the value of the supply concerned or the importation, as the case may be. (Republic of South Africa 1962:608) 
Therefore, for VAT implications to arise in South Africa, the transaction needs to meet the requirements of 'supply' of 'goods' or 'services' by a 'vendor' in 'the furtherance of any enterprise' (De Koker \& Kruger 2017). Each of the requirements will be considered in detail in this section and will be applied to the two research questions to ascertain as to whether output tax is chargeable or not (refer to Figure 2).

The first requirement for a transaction in South Africa to attract VAT is that the transaction should constitute a supply for VAT purposes. The definition of 'supply', section 1 of the Act reads verbatim as follows:

'supply' includes performance in terms of a sale, rental agreement, instalment credit agreement and all other forms of supply, whether voluntary, compulsory or by operation of law, irrespective of where the supply is effected, and any derivative of 'supply' shall be construed accordingly. (Republic of South Africa 1962:606)

For a supply to occur it is necessary that there should be a supplier and a recipient (De Koker \& Kruger 2017). Section 1 of the Act defines the recipient as 'the person to whom the supply is made' and the supplier as 'the person supplying the goods or services'. It is evident that the term 'supply' has a wide meaning (SARS 2017:39) and therefore it has to be explored further. The normal dictionary meaning of supply according to the English Oxford Living Dictionary (n.d.) is to 'provide' or 'to make something available'. A supply can also include a supply under a barter exchange transaction (De Koker \& Kruger 2017). A barter transaction is when goods or services are supplied for a consideration that is not money (De Koker \& Kruger 2017; SARS 2017:36). According to the SARS (2017:36) the consideration will be the open market value of the goods or services received. In the case of South Atlantic Jazz Festival (Pty) Ltd c CSARS (2015, ZAWCHC 8), the sponsors provided money, goods and services to the taxpayer for staging annual jazz festivals in Cape Town. In return the taxpayer provided goods and services to the sponsors in the form of branding and marketing. Both the taxpayer and the sponsors were VAT vendors. The courts held that output tax should be accounted for by the taxpayer as well as the sponsor in respect of taxable supplies.

Sections 8 and 18(3) of the Act contain provisions to ascertain whether a transaction is a supply or not or if the transaction is a supply of services or a supply of goods. Section 8 also deems certain transactions to be a supply, although they do not meet all the requirements, such as ceasing to be a vendor, indemnity payments, supplies to independent branches, fringe benefits, payments exceeding considerations, etc. None of these deemed supplies seems to be applicable to bitcoin transactions as set out in the two research questions.

The second requirement for a transaction in South Africa to attract VAT is that the supply should be either a supply of goods or a supply of services. The definition of 'goods', section 1 of the Act, reads verbatim as follows: 'goods' means corporeal movable things, fixed property, any real right in any such thing or fixed property, and electricity, but excluding -

(a) money;

(b) any right under a mortgage bond or pledge of any such thing or fixed property; and

(c) any stamp, form or card which has a value and has been sold or issued by the State for the payment of any tax or duty levied under any Act of Parliament, except when subsequent to its original sale or issue it is disposed of or imported as a collector's piece or investment article. (Republic of South Africa 1962:602).

The definition of 'money', section 1 of the Act, reads verbatim as follows:

'money' means -

(a) coins (other than coins made wholly or mainly from a precious metal other than silver) which the South African Reserve Bank has issued in the Republic in accordance with the provisions of section 14 of the South African Reserve Bank Act, 1989 (Act No. 90 of 1989), or which remain in circulation as contemplated in the proviso to subsection (1) of that section, and any paper currency which under the said Act is a legal tender;

(b) (i) any coin (other than coins made wholly or mainly from a precious metal) or paper currency of any country other than the Republic which is used or circulated or is intended for use or circulation as currency;

(ii) any bill or exchange, promissory note, bank draft, postal order or money order,

except when disposed of or importer as a collector's piece, investment article or item of numismatic interest. (Republic of South Africa 1962:603)

From the above definitions it is evident that bitcoins cannot be classified as 'goods' or subsequently 'money' in terms of the Act. The SARB (2014:2-5) issued a position paper in which it is explained that bitcoin does not have legal tender status (but is exchangeable for legal tender), and is also not electronic money as electronic money is redeemable for physical cash on demand, while bitcoins are tradable for cash. For normal taxation purposes both Berger (2016) and Wicht (2016) classified bitcoin as an asset in terms of the South African Income Tax Act 58 of 1962.

The definition of 'services', section 1 of the Act, reads verbatim as follows:

'services' means anything done or to be done, including the granting, assignment, cession or surrender of any right or the making available of any facility or advantage, but excluding a supply of goods, money, or any stamp, form or card contemplated in paragraph (c) of the definition of 'goods'. (Republic of South Africa 1962:605)

The general rule is that when a supply is not a supply of goods and also not specifically excluded from the definition of 'goods', it will be categorised as a supply of a service (De Koker \& Kruger 2017). 
The third requirement for a transaction in South Africa to attract VAT is that the transaction should constitute a supply of goods or services by a 'vendor' (De Koker \& Kruger 2017). This means that if a person is a vendor, they have to levy output tax on the selling price of their taxable supplies. According to section 1 of the Act a 'vendor' is any person 'who is, or is required to be, registered under this Act' (Republic of South Africa 1962:606). For purposes of this study, it is assumed that all parties involved in the bitcoin transactions are registered VAT vendors with SARS.

The fourth requirement for a transaction in South Africa to attract VAT is that the transaction should constitute a supply of goods or services by a vendor in the course or furtherance of an enterprise. An 'enterprise' is generally defined as any enterprise or activity, carried on continuously or regularly, in South Africa or partly in South Africa, by any person, in the course or furtherance of which, goods or services are supplied for a consideration, whether for profit or not (De Koker \& Kruger 2017). The definition of 'consideration', section 1 of the Act, reads verbatim as follows:

'consideration', in relation to the supply of goods or services to any person, includes any payment made or to be made (including any deposit on any returnable container and tax), whether in money or otherwise, or any act or forbearance, whether or not voluntary, in respect of, in response to, or for the inducement of, the supply of any goods or services, whether by that person or by any other person, but does not include any payment made by any person as a donation to any association not for gain. (Republic of South Africa 1962:598).

If all four of the above requirements of a transaction are met, output tax needs to be levied on the selling price of the goods or services. No output tax is levied on exempt supplies (De Koker \& Kruger 2017). Section 12 of the Act lists the exempt supplies and one exempt supply which could possibly be applicable to transactions involving bitcoins is the supply of financial services in terms of section 12(1) of the Act. This could be the case when bitcoin is exchanged for South African rand (research question 2). Therefore, it is necessary to determine if such transaction could be a potential exempt supply. Table 2 was used to analyse the supply of financial services that are exempt to determine if it could possibly include transactions relating to the exchange of bitcoin for South African rand. From the analysis performed, it is clear that the exchange of bitcoin for South African rand (research question 2) will not constitute a supply of financial services in terms of section 2 of the (current) Act.

\section{Results}

The VAT requirements explained in the previous section will result in the following output tax treatment based on the two research questions (also refer to Table 3 for a summary):

- Research question 1: The receiving of bitcoin in exchange for the selling of goods or rendering of services by a South African VAT vendor will be deemed to be a 'supply' of 'goods' or 'services' as it will constitute a barter transaction. It also meets the requirements of 'vendor' and
TABLE 2: Determine if research question 2 constitutes a financial service. Financial service (Republic of Research question 2: Application South Africa 1962:606)

Exchange of currency (whether effected by the exchange of bank notes or coin, by crediting or debiting accounts or otherwise (s 2(1)(a))

The issue, payment, collection or transfer of ownership of a cheque or letter of credit (s 2(1)(b))

Issue of a debt security (s 2(1)(c))

The issue or transfer of ownership of a share in a company or a member's interest in a close corporation (s 2(1)(d))

The provision of a loan as well as the paying of the interest (s 2(1)(f))

The provision or transfer of ownership of a long-term insurance policy (s 2(1)(i)) The provision or transfer of ownership in a superannuation scheme, such as a pension (s 2(1)(j))

The buying or selling of a derivative (as defined in International Accounting Standard 39) or the granting of an option (s 2(1)(k))

TABLE 3: Summary of conclusion based on interpretation of the Act.

\begin{tabular}{|c|c|c|}
\hline Criteria & Research question 1 & Research question 2 \\
\hline Supply & $\begin{array}{l}\text { The supply of goods or rendering } \\
\text { of services in exchange for } \\
\text { payment in bitcoin will constitute } \\
\text { a barter transaction. The value of } \\
\text { the supply will be measured as } \\
\text { the open market value of the } \\
\text { bitcoins received. }\end{array}$ & $\begin{array}{l}\text { - The supply of bitcoins in } \\
\text { exchange for payment in } \\
\text { South African rand will result } \\
\text { in a 'supply' as something is } \\
\text { made available or provided. }\end{array}$ \\
\hline $\begin{array}{l}\text { Goods or } \\
\text { services }\end{array}$ & $\begin{array}{l}\text { - Goods and services that are } \\
\text { subject to VAT are supplied or } \\
\text { rendered. }\end{array}$ & $\begin{array}{l}\text { - The supply of bitcoins to a } \\
\text { local exchange will not be } \\
\text { the supply of goods, but will } \\
\text { then automatically be the } \\
\text { supply of services. }\end{array}$ \\
\hline Vendor & - & - \\
\hline $\begin{array}{l}\text { In the } \\
\text { furtherance } \\
\text { of enterprise }\end{array}$ & $\begin{array}{l}\text { - The 'consideration' received in } \\
\text { this transaction is not actual } \\
\text { money (South African rand), } \\
\text { but 'otherwise'. }\end{array}$ & $\begin{array}{l}\text { - The 'consideration' received } \\
\text { for the exchange of bitcoins } \\
\text { for South African rand is } \\
\text { money. }\end{array}$ \\
\hline
\end{tabular}

'in the course or furtherance of an enterprise' as the goods or services are supplied for a consideration, which is not money, but something else, namely bitcoin (an asset as classified by Berger 2016, SARS 2018b and Wicht 2016 in terms of the South African Income Tax Act, No. 58 of 1962). It is therefore evident that output tax of $14 \%$ should be levied on the market value of the bitcoins on the day that the bitcoins are received in exchange for the goods or services. In the example provided in Figure 2 this will result in the South African VAT vendor (Entity A) having to account for output tax of R14 000 .

- Research question 2: The exchange of bitcoins by a South African VAT vendor for South African rand would constitute a 'supply' of 'services'. As bitcoins will not be treated as 'goods' in terms of the Act, it will automatically qualify as a supply of 'services' in exchange for consideration which is money (South African rand). Therefore, all the requirements are met and output tax of $14 \%$ should be levied on the value of the exchange (which is the South African rand received). It will not qualify as an exempt supply as it does not meet the requirements of a 'financial service' as set out in section 2 of the (current) Act. In the example provided in Figure 2 this will result in the same South African VAT vendor (Entity A) having to 
account for output tax of R31 370 (R255 $438 \times 14$ / 114). As a result the South African VAT vendor (Entity A) is 'double taxed'. Based on the assumption made under the methodology section on the information provided in Figure 1, this would result in output tax of R22 961883 (R186 $975337 \times 14$ / 114) to be accounted for by South African VAT vendors for the period 01 March 2017 to 28 February 2018.

\section{Conclusion and recommendations}

To conclude, it was shown through this study that the proposed treatment as explained in the previous section would impose 'double taxation': once on the selling of goods or rendering of services in exchange for bitcoins and once when the bitcoins are exchanged for South African rand. This output tax treatment could possibly result in a decrease in the use of bitcoin by South African taxpayers. Aggressive taxation policies on bitcoin could result in a delayed and limited growth for the South African exchange market and the bitcoin industry.

Against the background of the above, the following recommendations are made to the South African authorities to issue appropriate guidelines to taxpayers in terms of the output tax treatment of bitcoin transactions in South Africa:

- Treat both the receiving of bitcoins in exchange for the selling of goods or rendering of services, as well as the exchange of bitcoins for South African rand, as transactions that are subject to output tax at the standard rate of $14 \%$.

- Alternatively, treat the receiving of bitcoins in exchange for the selling of goods or rendering of services as a transaction that is subject to output tax at the standard rate of $14 \%$, but treat the exchange of bitcoins for South African rand as an exempt supply, in terms of the delivery of financial services.

Based on an interpretation of the (current) Act and with reference to the bitcoin exchange figures in South Africa, the first proposed treatment could result in decreasing the budget deficit should the exchange of bitcoins for South African rand be subject to output tax. This proposed treatment would therefore benefit the fiscus.

The second proposed treatment in the article corresponds with the Taxation Laws Amendment Bill of 2018 (National Treasury 2018:51) to include 'the issue, acquisition, collection, buying or selling or transfer of ownership of any cryptocurrency' by amending section 2(1) of the Act. This means that the exchange of bitcoins for South African rand by a South African VAT vendor will be treated as a financial service and will therefore be exempted from VAT. Should this proposed treatment be promulgated by National Treasury, the South African VAT vendor will obtain the benefit as no output tax will be levied on the exchange of bitcoins for South African rand.

Note: Since the article was accepted for publication, section 2(1) of the Act has been amended to include 'the issue, acquisition, collection, buying or selling or transfer of ownership of any cryptocurrency', effective from 01 April 2019.

\section{Recommended research}

The second research question of this article focused on the output tax implications for the South African VAT vendor who receives bitcoins in exchange for selling goods or rendering services, who then exchanges these bitcoins on a bitcoin exchange market for South African rand. In a follow up article both the input and output tax consequences are investigated for such vendor whose business is that of mining and trading with bitcoin.

\section{Acknowledgements}

The author would like to thank the anonymous reviewers for their time and input which has been most helpful in refining and improving this article. I sincerely believe that the revised article is of a much higher standard after the recommended changes.

\section{Competing interests}

The author declares that she has no financial or personal relationships that may have inappropriately influenced her in writing this article.

\section{References}

Ah Kun, A., 2014, 'INFLUENCE: Bitcoin the currency of the future?', Accountancy SA April, 34-35.

Australian Government, 2016, GST treatment of digital currency, Discussion Paper, Government Printers, Melbourne.

Australian Government: Australian Taxation Office (ATO), 2014, Tax treatment of crypto-currencies in Australia - specifically Bitcoin [Online], viewed 30 March 2017 from https://www.ato.gov.au/general/gen/tax-treatment-of-crypto-currencies-inaustralia---specifically-bitcoin/

Berger, L., 2016, 'Bitcoin exchange transactions: Income tax implications to consider within the South African environment', Unpublished master's thesis, North-West University, Potchefstroom.

Bitcoin ZAR, n.d., South African Bitcoin resources: The official site [Online], viewed 17 May 2018, from https://www.bitcoinzar.co.za/

Blockchain, n.d., [Online], viewed 22 May 2018, from https://blockchain.info/

BusinessTech, n.d., This graph shows just how popular Bitcoin is in South Africa [Online], viewed 17 May 2018, from https://businesstech.co.za/news/banking/ 218099/this-graph-shows-just-how-popular-bitcoin-is-in-south-africa/

Chuen, D.L.K. \& Deng, R.H., 2018, Handbook of blockchain, digital finance, and inclusion: Cryptocurrency, FinTech, InsurTech, regulation, ChinaTech, mobile security, and distributed ledger, Academic Press, London.

Davis Tax Committee, 2014, Addressing base erosion and profit shifting in South Africa Davis Tax Committee Interim Report, 30 June 2014, SARS, Cape Town.

De Kock, C., 2018, Data request response, email [Online], 21 May, chandler@luno.com

De Koker, A.P. \& Kruger, C., 2017, VAT in South Africa [Online], viewed 24 October 2017, from https://www.mylexisnexis.co.za/Index.aspx

English Oxford Living Dictionary, n.d., 'supply', [Online], viewed 20 July 2017, from https://en.oxforddictionaries.com/definition/supply

European Banking Authority (EBA), 2014, EBA Opinion on 'virtual currencies', Final report [Online], viewed 30 March 2017, from https://www.eba.europa.eu/ documents/10180/657547/EBA-Op-2014-08+Opinion+on+Virtual+Curencies.pdf

EY, 2016, Italian Tax Authorities clarify VAT treatment of Bitcoin transactions [Online], viewed 30 March 2017, from http://www.ey.com/gl/en/services/tax/internationaltax/alert-italian-tax-authorities-clarify-vat-treatment-of-bitcoin-transactions

Franco, P., 2015, Understanding Bitcoin: Cryptography, engineering and economics, John Wiley \& Sons, Chichester, IL.

HM Revenue and Customs (HMRC), 2014, Revenue and customs brief 9 (2014): Bitcoin and other cryptocurrencies [Online], viewed 26 June 2017, from https://www.gov. uk/government/publications/revenue-and-customs-brief-9-2014-bitcoin-anduk/government/publications/revenue-and-customs-brief-9-2014-bitcoin-and-
other-cryptocurrencies/revenue-and-customs-brief-9-2014-bitcoin-and-othercryptocurrencies 
Hutchinson, T. \& Duncan, N., 2012, 'Defining and describing what we do: Doctrinal legal research', Deakin Law Review 17(1), 83-119, viewed 27 June 2017, from legal research', Deakin Law Review 17(1), 83-119, view
https://ojs.deakin.edu.au/index.php/dr/article/view/70

Luno Exchange, 2018, Luno: The official site [Online], viewed 21 May 2018, from https://www.luno.com/trade/XBTZAR

Moskowitz, D., 2014, Singapore Tax Authorities (IRAS) recognize Bitcoin and give guidance [Online], viewed 27 June 2017, from https://coinrepublic.com/singaporetax-authorities-iras-recognize-bitcoin-and-gives-guidance/

Nakamoto, S., 2008, Bitcoin: A peer-to-peer electronic cash system [Online], viewed 09 November 2018, from https://bitcoin.org/bitcoin.pdf

National Treasury, 2014, User alert: Monitoring of virtual currencies, 18 September 2014, Government Printers, Pretoria.

National Treasury, 2018, Taxation Laws Amendment Bill (TLAB), National Treasury, Pretoria.

OECD, 2013, Action plan on base erosion and profit shifting, OECD Publishing, viewed 28 June 207, from https://doi.org/10.1787/9789264202719-en

OECD, n.d., List of OECD member countries - Ratification of the convention on the $O E C D$ [Online], viewed 09 November 2018, from http://www.oecd.org/about/ membersandpartners/list-oecd-member-countries.htm

Pasic, A., 2014, Singapore figured out how to tax bitcoin - Treat it like a product, not money [Online], viewed 27 June 2017, from https://qz.com/165207/singaporefigured-out-how-to-tax-bitcoin-treat-it-like-a-product-not-money/

PricewaterhouseCoopers, 2016, GST, Bitcoin and digital currencies, TaxTalk - Insights, March 2016, PwC London.

Ram, A.J., 2018, 'Taxation of Bitcoin: initial insights through a correspondence analysis', Meditari Accountancy Research 26(2), 214-240. https://doi.org/ 10.1108/MEDAR-10-2017-0229

Republic of South Africa, 1962, Value-Added Tax Act No. 89 of 1991, Government Printer, Pretoria.

Saunders, S., 2015, Cryptic currency [Online], viewed 19 June 2017, from https:// www.taxation.co.uk/Articles/2015/03/10/332784/cryptic-currency

Seforo, L., 2014, Currency and forex trading in the 21st century: Bitcoin [Online] viewed 19 June 2017, from http://taxstudents.co.za/currency-forex-trading-21stcentury-bitcoin/
Skatteverket v David Hedqvist [2015] C-264/14.

South African Reserve Bank (SARB), 2014, Position paper on virtual currencies, SARB, Pretoria.

South African Revenue Service (SARS), 2017, Legal counsel value-added tax, VAT404 Guide for Vendors, SARB, Pretoria.

South African Revenue Service (SARS), 2018a, Media release: SARS ready to implement VAT rate increase [Online], viewed 22 May 2018, from http://www.sars.gov.za/ Media/MediaReleases/Pages/27-March-2018---SARS-ready-to-implement-VATrate-increase.aspx

South African Revenue Service (SARS), 2018b, Media release: SARS's stance on the tax treatment of cryptocurrencies [Online], viewed 22 May 2018, from http://www. sars.gov.za/Media/MediaReleases/Pages/6-April-2018---SARS-stance-on-the-taxtreatment-of-cryptocurrencies-.aspx

South Atlantic Jazz Festival (Pty) Ltd c CSARS [2015] ZAWCHC 8.

Suberg, W., 2017, Australia just made a really smart Bitcoin decision [Online], viewed 19 June 2017, from http://www.valuewalk.com/2017/05/australiabitcoin-tax/

Thomas, T. \& Rudman, R., 2016, 'Bitcoin: Facilitating an African financial revolution', Accountancy SA June, 25-26.

Van Rooyen, W., 2018, The number of Bitcoins traded in South Africa, email [Online], 17 May, hello@wernervanrooyen.com

Visser, L., 2016, Where to spend Bitcoin in South Africa [Online], viewed 20 June 2017, from https://www.luno.com/blog/en/post/south-africa-pay-with-bitcoin

Wicht, M.S., 2016, 'The tax implications of Bitcoin in South Africa', Unpublished master's thesis, University of Pretoria, Pretoria.

Wiseman, S.A., 2016, 'Property or currency? The tax dilemma behind Bitcoin', Utah Law Review 2016(2), 417-440.

Young, J., 2017a, Australia will recognize Bitcoin as money and protect Bitcoin businesses, no taxes [Online], viewed 28 June 2017, from https://cointelegraph. $\mathrm{com} /$ news/australia-will-recognize-bitcoin-as-money-and-protect-bitcoinbusinesses-no-taxes

Young, J., 2017b, Should tax on Bitcoin be eliminated? The case of South Africa [Online], viewed 19 June 2017, from https://cointelegraph.com/news/should-taxon-bitcoin-be-eliminated-the-case-of-south-africa 